\title{
The Innovative Type of Technical and Skilled Talents and Training in Higher Vocational Colleges under Made-in-China 2025
}

\author{
Wanzhong QIN* \\ Tianjin Vocational Institute \\ Tianjin 300410, China \\ qinwanzhong1964@126.com
}

\begin{abstract}
Made-in-China 2025 Plan guides China's transition from a big manufacturing country to a powerful manufacturing country and higher vocational colleges shoulder the responsibility of training innovative type technical and skilled talents for our country. The intelligent production mode, distributed production organization, customized production process and networked labor organization in Made-in-China 2025 era give technical workers new meaning of labor contents and labor forms and ask workers to be compound talents with innovative ability and technology and skills. Based on the Sydney Accord, technical and skilled talents in Made-in-China 2025 era should be composed of three dimensions of professional ability, professional quality and professional action ability. From this point, training of innovative type technical and skilled talents in Made-in-China 2025 era need to construct an integrative talents training system, dual-subject school-enterprise cooperation running mode, professional action ability oriented curriculum and teaching model.
\end{abstract}

Keywords-made-in-China 2025; innovative type technical and skilled talents; higher vocational colleges; abilities and training

\section{INTRODUCTION}

With the rapid development of science, technology and social economy, the Made-in-China 2025 Plan has pointed out the direction for China's transformation from a big manufacturing country to a strong manufacturing country. In the era of intelligent manufacturing, large data and Internet of Things (IOT) systems are widely used in production, resulting in a new change in the production mode of manufacturing industry, which urgently needs innovative technical and skilled talents. Higher vocational education is an important system for training innovative type technical and skilled talents in China. Only by reconstructing their training system and training mode based on clarifying the connotation and ability characteristics of innovative type technical and skilled talents in the era of intelligent manufacturing can we cultivate innovative type technical and skilled talents to meet the needs of Made-inChina 2025.

\section{MADE-IN-CHINA 2025 PLAN AND THE CONNOTATION OF INNOVATIVE TECHNICAL SKILLED TALENTS}

\section{A. The necessity of Made-in-China 2025 Plan}

The Chinese government put forward the grand plan of "Made in China 2025" in 2015 based on studying the

This work was financially supported by the Tianjin education science “Thirteen-Five” planning project (project Number: VE3131) development trend of the world manufacturing industry and the problems existing in China's manufacturing industry. Its basic principles are: innovation-driven, quality first, green development, structural optimization and talent-based, its overall goal is: by 2050, the comprehensive strength of China's manufacturing industry will enter the ranks of the world's strong manufacturing country ${ }^{[1]}$. The necessity of Made-inChina 2025 includes: On the one hand, China's manufacturing 2025 plan accord with the new demands of "Industry 4.0" for the global manufacturing industry. Under the deep influence of information technology, especially the "Internet +", multidisciplinary and comprehensive cross boundary integration has greatly accelerated and deepened. Structural adjustment and industrial upgrading are major subjects facing any industry. Against this background, the United States, the European Union, Japan and other countries have proposed a national strategy to promote the transformation and upgrading of manufacturing industry to "intelligent" and an era of intelligent manufacturing represented by new energy, advanced materials, digital technology and robots is coming. On the other hand, the Made-in-China 2025 Plan is the guideline for the transformation of China turn into a strong manufacturing country. The scale of China's manufacturing industry has leapt to the first place in the world, but the level of the manufacturing industry is not so high that it is urgent to transform from a big manufacturing country to a strong manufacturing country.

\section{B. The connotation of innovative type technical and skilled talents}

Technical and skilled talents are the collective name of technical talents and skilled talents. It is a concept gradually improved with the development of science and technology. Technology is a special field of human activities, and early technology only refers to applied technology. At the beginning of the 20th century, the meaning of technology gradually expanded to tools, machines and the methods and processes of their use. In modern society, technology refers not only to technology and skills, but also to the use of scientific knowledge to solve problems. With the development of science and technology, the evolution of industrialization and the transformation of enterprise production mode, people subdivide technology according to the needs of production practice. The technology needed to transform scientific 
principles into engineering design, work plan and operation decision-making is called engineering technology, and the corresponding talents are "engineering talents". Talents who put the concepts of design, work plan and operation decision into practice and turn them into material forms such as products and engineering are collectively called "skilled talents". And the talents that between "engineering talents" and "skilled talents" are now commonly referred "technical talents", they should not only master the theory technology, but also understand the experience technology ${ }^{[2]}$.

The Ministry of Education has put forward six standards for innovative type talents : (1)Have a certain knowledge base and a strong thirst for knowledge;(2)have innovative consciousness and passion;(3)have ability to identify and analyze problems;(4) have a spirit of down-to-earth and not afraid difficulties; (5) have the ability to transform achievements under the guidance of market;6have team spirit, sense of responsibility and sound physique $^{[3]}$. Thus, innovative type talents refer to the talents that with innovative consciousness, innovative spirit, innovative ability, innovative character and innovative personality. Innovative talents can be divided into research type, application type and skill type and the corresponding educational levels are graduate education, undergraduate education and higher vocational education. Innovative type talents in higher vocational education are mainly concentrated in the technology application field, focusing on the cultivation of students' innovative spirit and practical ability. Therefore, innovative type technical and skilled talents refer to those talents who have solid theoretical knowledge, comprehensive practical ability, innovative thinking and excellent psychological quality.

III. THE CHARACTERISTICS OF INNOVATIVE TYPE TECHNICAL AND SKILLED TALENTS IN THE ERA OF INTELLIGENT MANUFACTURING

\section{A. Production characteristics of traditional manufacturing enterprises}

Since the emergence of industrial society, with the progress of science and technology and the leap-forward development of industrial civilization, the production mode of manufacturing industry has experienced four main forms: craft production, mass production (Ford system), lean production (Toyota system) and intelligent production in the industrial 4.0 era. Different production modes have different requirements for technical and skilled talents. The early manufacturing industry mainly adopted the craft production mode, without the division of technical or skilled talents, all workers are all-round producers and operators. In the first half of the 20th century, with the invention and use of electric power technology, the manufacturing industry mainly adopted mass production. Production organizations are divided into two dimensions: labor content and labor management, which are divided into meticulous stick and severe rank ${ }^{[4]}$. At this time, the division of labor is clear, and the technical talents and skilled talents are strictly divided. In the second half of the 20th century, the rapid development of electronic information technology has improved the level of production automation. The manufacturing industry mainly adopts lean production of many varieties and small batches ${ }^{[5]}$. Lean production combines the advantages of craft production and mass production. At this time, technical and skilled talents show a trend of integration. They need to master complex types of work, cross-professional knowledge and operational skills, have the ability of social interaction and cooperation, have certain leadership, decisionmaking ability and problem-solving ability, have quality awareness, have lifelong learning and innovation ability.

\section{B. Production characteristics of enterprises in the intelligent manufacturing era}

Since the beginning of the 21st century, network technology, information technology, computer technology and software technology have developed rapidly, rapidly entered the manufacturing industry and deeply integrated with automation technology. Intelligent manufacturing technology is formed by the combination of artificial intelligence technology, robotics technology and digital manufacturing technology, so intelligent production is produced. In the era of intelligent manufacturing, the production mode of enterprises realizes the collaborative dialogue between people, people and machines, machines and machines on the basis of Internet, thus realizing "intelligent" production, flexible manufacturing and interconnected manufacturing. In the era of intelligent manufacturing, driven by both personalized demand and information network technology, the production organization mode of enterprises will develop towards distributed manufacturing, that is, the production system of enterprises is more like a unitary factory. Distributed manufacturing operates in a way similar to social networks, which automatically connect to cloud platforms to search for appropriate orders and upload production-related questions for expert advice. Experts will be more effective in remote maintenance and services through integrated knowledge platforms and mobile devices ${ }^{[6]}$. Distributed production can quickly and efficiently meet the individualized needs of the market, make full use of production resources, reduce production costs and ensure product quality. In the era of intelligent manufacturing, manufacturing process is a process of customization, which is an intelligent network weaving raw materials, intelligent factories, logistics distribution and consumers together. In the era of Intelligent Manufacturing, in order to respond quickly to the individualized demand of the market, with the support of information network technology, dynamic alliances among enterprises are bound to be constructed to realize the integration of social resources within and across enterprises, thus extending the division of labor from within enterprises to outside enterprises, showing a trend of dynamic combination.

\section{The labor content and connotation of innovative type technical and skilled talents in the intelligent manufacturing era}

The production characteristics of enterprises in the era of intelligent manufacturing determine that the labor task of frontline skilled workers is to operate and manage the production systems which intelligent and integrated. Specific work contents include: carrying out operation process tasks with parameters; debugging equipment to ensure the optimization of production process; analyzing, collating and recording production data; analyzing, monitoring, optimizing and improving production network and system; using and jointly 
designing the help and diagnosis system supported by IT; understanding and optimizing the network relationship with upstream and downstream enterprises; and carrying out equipment failure diagnosis, exclusion, maintenance, etc. In order to accomplish these tasks, skilled workers should have the following abilities: the perception ability of integrated tasks; the knowledge of information technology, production technology and software structure; the ability to create userfriendly interfaces and develop software jointly; the ability to adjust production plans, optimize production systems and make independent decisions according to demand changes; and the ability to operate, maintain and repair complex mechanicalelectrical integration equipment; can correctly read and evaluate machine data and intervene in the machine; have the ability to acquire knowledge through the Internet, manuals, data tables and knowledge forums. In short, in the era of intelligent manufacturing, the skilled workers in the front line of production must be knowledge workers. They should be innovative type technical and skilled talents with innovation, technology and skills. There will no longer be a single technical talent with the implicit intelligence characteristics or skilled talents with the explicit action characteristics.

\section{Ability characteristics of innovative type technical and skilled talents in the intelligent manufacturing era}

In order to effectively train skilled workers who have innovation, technology and skills together in intelligent manufacturing, and facilitate the construction and establishment of vocational education training system, educational objectives, curriculum content and teaching mode, starting from the connotation of innovative type technical and skilled talents, based on the "Sydney Agreement" paradigm vocational competence evaluation model ${ }^{7]}$, innovative type technical and skilled talent ability model oriented to intelligent manufacturing can be constructed. It is divided into three dimensions. (1) Professional dimension: including general knowledge, intelligent knowledge and technology, industrial production chain knowledge, professional knowledge and skills. They are not only the scope of contents that need to be learned in the process of developing the vocational ability, but also the source of the test questions of the vocational ability for innovative type technical and skilled talents. (2)Professional accomplishment dimension: including professional ethics, decision-making ability, innovative spirit and social ability. Firstly, having professional ethics is one of the most basic professional qualities, and it is also the basic professional ability of innovative type technical and skilled talents should possess in the era of intelligent manufacturing. Secondly, in the era of intelligent manufacturing, the intellectualization of production mode, the distribution of production organization and the customization of the manufacturing process will inevitably lead to the reengineering of the production process, the reorganization of value chain and the knowledge-intensive of production process, which require the skilled workers to have the ability of decision-making, lifelong learning and continuous innovation. Finally, the grid of labor organization in the era of intelligent manufacturing requires that the working attitude of skilled workers tend to be cooperative and efficient, possess the self-cultivation and skills to cooperate with different opinion values, different classes of people, and have the spirit of contract and the concept of time. (3)Vocational action dimension: including information acquisition, planning, decision-making, implementation, control and evaluation, which constitute a complete mode of action to complete the "production task". Complete action mode is the actual operation law of vocational work and the logical law that students should follow in their learning activities. Whether the learners follow the complete action mode greatly affects the acquisition of working process knowledge and the development of their comprehensive professional competence.

\section{THE TRAINING OF INNOVATIVE TYPE TECHNICAL AND SKILLED TALENTS UNDER THE BACKGROUND OF MADE-IN- CHINA 2025}

\section{A. Construct the training system of innovative type technical and skilled talents}

Intelligent manufacturing needs knowledge workers who integrate innovation, technology and skills and engage in intelligent production. At present, our country's vocational education talents training system from secondary to higher vocational education mainly emphasizes the cultivation of students' comprehensive vocational skills across major and large types of work, which can not meet the requirement of intelligent manufacturing for the overall shift of skilled workers' ability needs ${ }^{[8-9]}$. Therefore, it is necessary to reform the vocational education system, build an overpass for vocational education personnel training, and open up the training channels from secondary vocational to higher vocational education. Firstly, we should integrate the advantageous resources of each education section in talents training, and give full play to its overall effect. Secondly, we should organize and coordinate the operation of the training system from the perspective of system theory, clearly define the training objectives of each section, not only ensure that each section has a certain emphasis on talent ability training, but also realize the continuous accumulation and system construction of talent capacity. Finally, each section should establish and improve the quality control system, clarify its position and role in the training system, develop normative talent capacity standards according to the requirements of intelligent manufacturing, and strengthen the monitoring and assessment to talent training quality according to the standards, so as to ensure the realization of the overall goal of the innovative type technical and skilled talents training system for intelligent manufacturing.

\section{B. Construct the double-main-body running mode of school- enterprise cooperation}

According to the ability model of innovative type technical and skilled talents facing intelligent manufacturing, the knowledge worker with professional action ability is needed in intelligent manufacturing. The cultivation of vocational action ability must have the deep involvement of enterprises and the degree of enterprise participation is directly related to whether the cultivation of technical and skilled talents meets the requirements of intelligent manufacturing. However, for a long time, due to many reasons, there has been a serious phenomenon of school initiative and enterprise passivity in school-enterprise cooperation in China, which has become the bottleneck restricting the training of technical and skilled 
talents. The reason is that in the design of vocational education system in China, the interests of enterprises as stakeholders of vocational education are neglected. In order to change this phenomenon in school-enterprise cooperation, scholars have put forward different countermeasures and suggestions from different perspectives. For example, to formulate laws and regulations binding on enterprises, to force enterprises to participate in the training of talents in Vocational Colleges through legislation; or to formulate relevant policies and regulations, to encourage enterprises to participate in the training of talents in vocational education through government tax relief.

\section{Construct the curriculum model of vocational action ability orientation}

In the era of intelligent manufacturing, innovative type technical and skilled talents need to possess the operation and management ability of intelligent production system, the working method ability in a dynamic working environment and social ability. Accordingly, the curriculum system of vocational education should be reconstructed adaptively at the two aspects of curriculum structure and content. In terms of curriculum structure, we should add some knowledge in the fields of innovation education, intellectualization, informatization and network to the traditional curriculum system as a general course. To enable students to master advanced network technology and intelligent testing and sensing technology, so lay a solid foundation for students to use the Internet of Things, the Internet and large network data platform for production and innovation. In terms of curriculum content, the traditional curriculum field knowledge should be updated and modernized. The professional curriculum can learn from the latest research results of German vocational education curriculum reform, follow the logical sequence of the work process, and construct a typical occupational situation oriented learning field curriculum system. In the era of intelligent manufacturing, innovative technical and skilled talents should make decision, control and coordination on the operation of intelligent equipment, organize and coordinate virtual network and real machine, and coordinate the interaction between the control system and management system according to the requirements of customers. That is to say, technical and skilled talents should use knowledge and information to plan, coordinate, evaluate and make decisions according to the needs of specific customers. That is said, their professional actions have strong situation-oriented dynamic characteristics. This requires the professional curriculum content of vocational education, best be the learning field come from a typical vocational situation that treated by teaching theory, to ensure that students can acquire vocational action ability and ability transferability.

\section{Construct the teaching mode of vocational action ability orientation}

Professional action ability is human's ability and willingness to think rationally, engage in professional work and assume social responsibility in the professional situation. In the era of intelligent manufacturing, higher vocational colleges should focus on training students' vocational action ability. The research results show that action-oriented teaching mode is an effective mode to cultivate students' vocational action ability. The so-called action-oriented teaching mode is to design "meaningful learning tasks" or "useful action results", so that students can form professional action ability by actual "doing" in the process of completing specific tasks, the mode emphasize thinking and summing up experience in the process of "doing". In designing "meaningful learning tasks", we should pay attention to the following aspects. Firstly, learning tasks should come from real typical career situations as far as possible, to be complete and have appropriate problem components, and the professional working process should be clear and transparent. Secondly, students' experience and interest should be taken into account as much as possible, and students' autonomous learning should be emphasized, so as to mobilize them to devote themselves wholeheartedly to learning Thirdly, it includes innovative problems, to create as much decision-making and action space as possible for students, so as to improve their flexibility in solving problems. Finally, learning tasks should promote communication and cooperation among students.

\section{V.CONCLUSION}

The intelligent production mode gives technical workers new meaning of labor contents and labor forms, Only through thorough reform of talents training system and talents training mode in higher vocational education, can innovative type technical and skilled talents that meet the requirements of Made-in-China 2025 be trained.

\section{REFERENCES}

[1] G.W. Zheng. Manufacturing Technology and Machine Tools, [J], 2018, No.9, p.7-9. (In Chinese)

[2] Y. Pei. Vocational and Technical Education in China, [J], 2003, No.20, p.37-38. (In Chinese)

[3] Y. Li, J. Fu. Occupation, [J], 2013, No.32, p.55-56. (In Chinese)

[4] [U.S.A]Taylor: Principles of Scientific Management[M], (L.C. Hu. Etc. Translate. China Social Science Press, China 1984). (In Chinese)

[5] M.G. Li. Research on Higher Engineering Education, [J],2016, No.5, p.57-65. (In Chinese)

[6] Z.W. Chen. World Science, [J],2014, No.5, p.6-13. (In Chinese)

[7] Z.L. Tang, etc.. Zheng. Vocational and Technical Education, [J] ,2017, No.4, p.75-79. (In Chinese)

[8] G.Q. Xu. Educational Research, [J], 2016, No.3, p.72-78. (In Chinese)

[9] T. Xu. Journal of Changchun University of Science and Technology, [J],2012, No.9, p.39-40. (In Chinese) 